\title{
Evaluasi Penerapan Insinerator Sampah Skala Kecil di TPST Kabupaten Sidoarjo
}

\section{Evaluation of Small Scale Municipal Solid Waste Incinerators Application at TPST Sidoarjo Regency}

\author{
WAHYU PURWANTA \\ Pusat Teknologi Lingkungan, Badan Pengkajian dan Penerapan Teknologi (BPPT) \\ Gedung 820 Geostech Lt.3, Kawasan Puspiptek Serpong, Tangerang Selatan \\ Email: wahyu.purwanta@bppt.go.id.
}

\begin{abstract}
The waste's production rate in Sidoarjo Regency is estimated at 1,216 tpd. Around 464 tpd (ton per day) are transported to Jabon Landfill, and about 298 tpd are treated at the Integrated Garbage Treatment Center (TPST), 3R Treatment Center, and the Bank of Garbage. Therefore, there are still 454 tpd of waste that has not yet been managed, potentially harming the environment. The still limited garbage service level to be transported to the landfill has made the community take the initiative to process the garbage with incinerators placed at the existing TPST. These incinerators can reduce the waste up to $25 \%$ to $30 \%$ by weight of the waste that enters the TPST. In this research, ten incinerators were studied in the TPST. From the sample conditions obtained, almost all incinerators were operated below the technical standards required for optimum operation and minimum environmental impact. The combustion temperature is generally below $800{ }^{\circ} \mathrm{C}$, the gas residence time is less than 2 seconds, and there is no turbulence. Therefore, the black smoke often occurs due to incomplete combustion. Air pollution control installations such as cyclones and scrubbers are malfunctioning and rusty due to high temperatures and acidic environments. Incinerator management hardly relies on community contributions. However, it is generally only enough for employee salaries. Furthermore, there is no incinerator maintenance. On the other hand, social conflicts due to incinerator smoke are reported to have not yet occurred because the location of TPST is generally still far from residential areas.
\end{abstract}

Keywords: incinerator, small scale, operation, environmental

\begin{abstract}
ABSTRAK
Tingkat timbulan sampah Kabupaten Sidoarjo adalah 1.216 ton/hari, dimana sekitar 464 ton dibawa ke TPA Jabon dan 298 ton ditangani di TPST, TPS 3R, dan Bank Sampah. Hal ini berarti masih ada 454 ton sampah yang tidak terkelola dan berpotensi lari ke lingkungan. Masih terbatasnya tingkat pelayanan sampah untuk diangkut ke TPA telah membuat masyarakat berinisiatif mengolah sampahnya dengan insinerator yang ditempatkan di TPST yang ada. Keberadaan insinerator ini mampu mengurangi berat sampah hingga $25 \%$ hingga $30 \%$ berat sampah yang masuk ke TPST. Melalui penelitian terhadap sepuluh insinerator di TPST, diperoleh kondisi bahwa hampir semua insinerator beroperasi di bawah standar teknis yang dipersyaratkan bagi tercapainya operasi optimum dan minimnya dampak lingkungan. Suhu pembakaran umumnya berada di bawah $800{ }^{\circ} \mathrm{C}$, waktu tinggal gas kurang dari 2 detik dan tidak terjadi turbulensi, sehingga sering terjadi asap yang hitam akibat pembakaran tidak sempurna. Kondisi instalasi pengendalian pencemaran udara seperti cyclone dan scrubber banyak yang tidak berfungsi dan berkarat akibat tidak tahan suhu tinggi dan lingkungan yang asam. Pengelolaan insinerator mengandalkan iuran warga namun umumnya hanya cukup untuk honor pekerja sehingga tidak ada untuk perawatan insinerator. Konflik sosial akibat asap insinerator belum terjadi karena lokasi TPST umumnya masih jauh dari permukiman warga.
\end{abstract}

Kata Kunci: insinerator, skala kecil, operasi, lingkungan

\section{PENDAHULUAN}

\subsection{Latar Belakang}

Pertumbuhan jumlah penduduk yang juga diiringi meningkatnya aktivitas ekonomi warga menyebabkan meningkatnya kebutuhan prasarana dasar sanitasi. Demikian halnya di Kabupaten Sidoarjo, kegiatan ekonomi utama sudah bergeser menuju sektor sekunder dan tersier dalam era 10 tahun terakhir. Sektor industri pengolahan selalu menyumbang di atas $45 \%$ dari nilai tambah kegiatan ekonomi. Naik turunnya kegiatan ekonomi di sektor ini akan sangat berpengaruh terhadap pertumbuhan ekonomi di Kabupaten Sidoarjo(1). Meningkatnya jumlah penduduk dan aktivitas ekonomi 
berdampak pula pada semakin meningkatnya timbulan sampah di Kabupaten Sidoarjo.

Berdasarkan data jumlah penduduk Sidoarjo tahun 2018 sebanyak 2.223.002 jiwa serta laju timbulan sampah untuk kota sedang sebesar 0,50 kg/orang/hari maka akan diperoleh perkiraan timbulan sampah sebanyak 1.111,52 ton/hari(2). Namun mengingat di Kabupaten Sidoarjo sendiri banyak pendatang termasuk pekerja dan pelajar dari daerah lain yang tidak tercatat dalam data kependudukan, maka bisa diduga bahwa timbulan sampah lebih dari angka tersebut, ini bisa dilihat dari data Dinas Lingkungan Hidup dan Kebersihan yang merilis angka timbulan sampah sebesar 1.216 ton/hari. Timbulan sampah 1.216 ton/hari tersebut sekitar 464 ton dibawa ke Tempat Pemrosesan Akhir (TPA) Jabon dan 298 ton di tangani di Tempat Pemrosesan Sampah Terpadu (TPST), TPS 3R, dan Bank Sampah, ini berarti masih ada 454 ton sampah yang tidak terkelola dan berpotensi lepas ke lingkungan.

Konsep TPST ini sebenarnya lahir karena luasnya wilayah Kabupaten Sidoarjo yang menyebabkan adanya kendala transportasi sampah (jarak tempuh) ke TPA sehingga sedapat mungkin sampah dapat dikelola di TPST Menurut Permen PU nomor 3 tahun 2013, TPST adalah tempat dilaksanakannya kegiatan pengumpulan, pemilahan, penggunaan ulang, pendauran ulang, pengolahan, dan pemrosesan akhir.

Saat ini terdapat 116 TPST (86 kondisi aktif) dan 5 TPST Kawasan yang tersebar di berbagai desa se Kabupaten Sidoarjo ${ }^{(3)}$. Pengelolaan sampah di TPST sendiri umumnya terdiri atas pemilahan material yang bernilai ekonomi, pengomposan sampah organik dan pembakaran sisa sampah hasil pemilahan. Namun berdasar survei di lapangan, aktivitas pengomposan telah lama ditinggalkan dan hanya dilakukan pada skala kecil di rumah-rumah pengomposan atau TPS 3R. TPS 3R adalah tempat dilaksanakannya kegiatan pengumpulan, pemilahan, penggunaan ulang, dan pendauran ulang skala kawasan(4). Sedangkan kondisi tungku pembakaran sampah (dalam studi ini secara praktis disebut insinerator skala kecil) banyak yang beroperasi di bawah standard pengoperasian yang seharusnya atau malah sudah tidak beroperasi sama sekali. Kinerja pengoperasian insinerator yang baik dapat dicapai jika memenuhi unsur 3T, yakni Temperature, Turbulence, dan Time. Sedangkan kinerja lingkungan diukur berdasar besaran parameter dalam emisi gas buangnya yang harus memenuhi baku mutu emisi dalam Peraturan Menteri Lingkungan Hidup dan Kehutanan No.70 tahun $2016^{(5)}$.
Temperatur minimal di tungku adalah $850{ }^{\circ} \mathrm{C}$ untuk memastikan terjadinya pembakaran yang sempurna serta mencegah terbentuknya dioksin/furans. Turbulensi gas harus terbentuk mekanisme percampuran sampah saat dibakar sedang waktu tinggal gas (Time) minimal 2 detik. Selain itu insinerator juga harus dilengkapi instalasi pengendalian pencemaran udara (IPPU) seperti cyclone, scrubber dan cerobong. Untuk memastikan sampah dapat terbakar sempurna harus dipastikan kecukupan antara suplai bahan bakar dan udara yang mencukupi. Salah satu indikator visual sederhana untuk kinerja pembakaran yang baik adalah asap yang relatif bening atau putih tipis yang keluar dari cerobong. Sistem pembakaran sampah dengan insinerator skala kecil yang tidak dilengkapi IPPU dan tidak dioperasikan secara benar akan berpotensi membawa dampak ke lingkungan termasuk permasalahan sosial yakni adanya protes dari warga terkait pencemaran udara dan asap ${ }^{(6)}$ Tulisan ini memaparkan hasil studi evaluasi penerapan insinerator skala kecil berdasar sistem pengoperasian dan pengamatan dampaknya di beberapa TPST di Kabupaten Sidoarjo yang dilakukan pada Nopember 2019. Hasil evaluasi akan digunakan dalam pengambilan kebijakan oleh Dinas Lingkungan Hidup dan Kebersihan atas kelanjutan pengoperasiannya.

\subsection{Tujuan Penelitian}

Penelitian ini bertujuan mengevaluasi penerapan insinerator skala kecil (modular) di sembilan lokasi TPST sebagai masukan kebijakan kepada Pemerintah Kabupaten Sidoarjo. Diharapkan data dan hasil evaluasi bermanfaat bagi perbaikan penerapan dan pengoperasian insinerator skala kecil di masa datang dengan meminimalkan dampak ke lingkungan serta pengelolaan yang berkelanjutan.

\section{BAHAN DAN METODE}

\subsection{Bahan dan Alat}

Evaluasi dilakukan dengan menggunakan materi dokumen perencanaan desain insinerator sebagai pembanding dengan insinerator yang terbangun, pengukur jarak (meteran), timbangan, dan pengukur suhu (termometer).

\subsection{Metode Penelitian}

Metode penelitian dilakukan dengan desk study dan pengamatan langsung serta wawancara dengan pengelola TPST. Desk study untuk mengkaji dokumen perancangan dan data sekunder kinerja peralatan, sedangkan pengamatan lapangan dilakukan untuk mengevaluasi posisi lokasi insinerator, neraca 
massa sampah di TPST sampel, kinerja pembakaran yang direpresentasikan suhu, sistem grate/percampuran sampah, suplai udara, tata kelola insinerator, dan pengamatan visual terhadap asap pembakaran.

Dari 116 TPST yang ada ditetapkan 9 TPST digunakan sebagai sampel untuk evaluasi insinerator dalam studi ini meliputi TPST Lingkar Timur, Randegan, Sukorejo, Kragan, Kedondong, Damarsi, Suruh, Ponokawan, dan Taman. Ke sembilan sampel insinerator mewakili jenis-jenis insinerator yang ada di seluruh TPST di Kabupaten Sidoarjo. Ke sembilan TPST tersebut mewakili berbagai jenis/tipe tungku bakar yang ada di TPST Kabupaten Sidoarjo.

\section{HASIL DAN PEMBAHASAN}

\subsection{Timbulan, komposisi dan karakteristik sampah}

Studi timbulan, komposisi dan karakteristik sampah di Kabupaten Sidoarjo menggunakan data sekunder serta verifikasi di lapangan. Timbulan sampah di Kabupaten Sidoarjo mencapai 1.216 ton/hari dan dalam dokumen Jakstrada Pengolahan Sampah 2018 disebutkan mencapai $4.400 \mathrm{~m}^{3} /$ hari, jika angka ini valid maka densitas sampah mencapai $276 \mathrm{~kg} / \mathrm{m}^{(3,7)}$. Berdasar penelitian yang dilakukan Badan Pengkajian dan Penerapan Teknologi (BPPT) pada tahun 2010, kota kecil memiliki laju timbulan 0,45 - 0,52 kg/org/hari dan kota sedang pada 0,53 - 0,55 kg/org/hari(8). Walau jumlah penduduk Kabupaten Sidoarjo hampir 2 juta jiwa, tidak otomatis Kabupaten Sidoarjo dapat menggunakan angka timbulan sampah kategori kota metropolitan, hal ini karena pola perkotaan hanya dibentuk dari beberapa kecamatan, sehingga lebih tepat menggunakan angka timbulan kota sedang.

Komposisi sampah rumah tangga di Kabupaten Sidoarjo berubah dari tahun ke tahun. Dari dua sumber data yakni dari Dinas Kebersihan dan Pertamanan (DKP) tahun 2013 dan dokumen Jakstrada 2018 terdapat sedikit perubahan persentase komposisi sampah. Komponen sampah tertinggi dari tahun 2013 dan 2018 adalah sampah organik yang berupa sampah sisa makanan dan dapur sebesar $65 \%$ dan naik ke 68,17\%. Kedua tertinggi adalah sampah plastik yaitu sebesar $15,5 \%$ pada tahun 2013 dan turun ke angka 12,75\% pada tahun 2018. Jenis sampah lainnya seperti kertas, kayu, kain, kertas, kaca dan B3 jumlahnya tidak signifikan dan secara umum turun dari tahun 2013 ke 2018. Namun yang mengejutkan dari data tahun 2018 ini adanya sampah popok yang mencapai 9,33\%, ini meneguhkan bahwa sampah plastik dan popok yang saat ini disorot sebagai sampah yang mencemari perairan semakin terbukti. Baik plastik maupun popok merupakan sampah yang tidak bisa begitu saja dibakar, apalagi jika pembakaran tidak dalam suhu tinggi $\left(>900{ }^{0} \mathrm{C}\right)^{(9,10,11)}$. Variasi nilai komposisi sampah Kabupaten Sidoarjo diperlihatkan dalam Tabel 1.

Tabel 1. Komposisi sampah di Kabupaten Sidoarjo

\begin{tabular}{|c|c|c|c|}
\hline No & Komponen Sampah & $\begin{array}{l}\text { Tahun } \\
2013^{i)}\end{array}$ & $\begin{array}{l}\text { Tahun } \\
\text { 2018ii) }\end{array}$ \\
\hline 1 & Organik & $65,00 \%$ & $68,17 \%$ \\
\hline 2 & Kertas & $5,30 \%$ & $4,95 \%$ \\
\hline 3 & Plastik & $15,50 \%$ & $12,75 \%$ \\
\hline 4 & Kayu & $2,70 \%$ & $0,97 \%$ \\
\hline 5 & Kain/Tekstil & $4,50 \%$ & $1,32 \%$ \\
\hline 6 & Karet/kulit tiruan & $0,19 \%$ & $0,15 \%$ \\
\hline 7 & Logam/Metal & $1,50 \%$ & $0,15 \%$ \\
\hline 8 & Gelas/Kaca & $0,50 \%$ & $0,65 \%$ \\
\hline 9 & Limbah Berbahaya & $1,25 \%$ & $0,14 \%$ \\
\hline 10 & Limbah Pembongkaran & $0,81 \%$ & - \\
\hline 11 & Popok & - & $9,33 \%$ \\
\hline \multirow[t]{2}{*}{12} & Lain-lain & $2,75 \%$ & $1,43 \%$ \\
\hline & Total & $100,00 \%$ & $100,00 \%$ \\
\hline
\end{tabular}

Sumber: i) DKP Kabupaten Sidoarjo (2013), ii) Jakstrada (2018)

\subsection{Insinerator dalam sistem pengelolaan sampah}

Keberadaan insinerator skala kecil di Sidoarjo merupakan bagian dari sub sistem pengelolaan sampah setempat yang memiliki pola kumpul - angkut - proses antara - proses akhir. Insinerator berada pada posisi pemrosesan antara baik di TPS maupun TPST. Keberadaan insinerator turut membantu mengurangi beban sampah yang harus diangkut ke TPA, karena insinerator membakar residu dari proses pemilahan dengan kategori sampah yang dapat terbakar (combustible). Pengamatan terhadap 4 (empat) TPST diperoleh angka pengurangan sampah bisa mencapai $25 \%$ hingga $30 \%$ dari input sampah yang masuk ke TPST seperti dalam kasus TPST Damarsi, TPST Ponokawan dan TPST Suruh 2. Pengamatan terhadap TPST Taman tidak dapat dilakukan karena kondisi insinerator sedang dalam keadaan non aktif. Di satu sisi memang keberadaan insinerator memang turut membantu mengurangi beban sampah yang harus ke TPA, karena insinerator membakar residu pemilahan dalam proses daur ulang yang dapet terbakar (combustible). Angka pengurangan sampah bisa mencapai $30 \%$ dari input sampah yang masuk ke TPST seperti dalam kasus TPST Damarsi. 
Pengurangan $30 \%$ ini ditambah proses daur ulang yang mampu mengambil sampah sekitar $57 \%$ berakibat sampah yang di bawa ke TPA tinggal $13 \%$ dari sampah yang masuk ke TPST. Angka sedikit berbeda di TPST Suruh Sukodono dimana tungku bakar mampu mengurangi sampah $27 \%$ sedangkan daur ulang mengurangi $35 \%$ sehingga sampah yang diangkut ke TPA sebanyak $38,7 \%$ sekitar 0,87 ton/hari. Hal ini karena saat dilakukan survei hanya satu tungku yang beroperasi (unit 2) sedangkan satu tungku lainnya tidak lagi dioperasikan (unit 1). Tabel 2 memperlihatkan kondisi neraca aliran sampah di sembilan TPST terlihat bahwa ada peran signifikan dari insinerator di TPST. Namun demikian pengoperasian insinerator yang tidak sesuai kaidah yang benar tentu juga menimbulkan masalah tersendiri baik dari segi kinerjanya, aspek sosial dan dampak ke lingkungan ${ }^{(12,13)}$. Sejauh ini belum ada konflik sosial terkait keberadaan insinerator karena lokasinya yang masih jauh dari lingkungan perumahan.

Tabel 2. Neraca Aliran Massa Sampah di TPST Sampel

\begin{tabular}{llllll}
\hline No & Lokasi TPST & Input sampah & Dibakar/insinerator & Pemilahan/ Daur ulang & Diangkut ke TPA \\
\hline $\mathbf{1}$ & Lingkar Timur & $\mathbf{1 2 , 0}$ ton $(100 \%)$ & 0,75 ton $(6,3 \%)$ & 8,40 ton $(70 \%)$ & 2,85 ton $(24 \%)$ \\
\hline $\mathbf{2}$ & Randegan & 10,0 ton $(100 \%)$ & 3,00 ton $(30 \%)$ & 5,50 ton $(55 \%)$ & 1,50 ton $(15 \%)$ \\
\hline $\mathbf{3}$ & Sukorejo & 2,75 ton $(100 \%)$ & 0,90 ton $(33 \%)$ & 1,25 ton $(45 \%)$ & 0,60 ton $(22 \%)$ \\
\hline $\mathbf{4}$ & Kragan & 2,20 ton $(100 \%)$ & 0,60 ton $(27 \%)$ & 1,15 ton $(52 \%)$ & 0,45 ton $(21 \%)$ \\
\hline $\mathbf{5}$ & Kedondong & 2,65 ton $(100 \%)$ & 0,85 ton $(32 \%)$ & 1,65 ton $(56 \%)$ & 0,50 ton $(12 \%)$ \\
\hline $\mathbf{6}$ & Damarsi & 3,00 ton $(100 \%)$ & 0,90 ton $(30 \%)$ & 1,70 ton $(57 \%)$ & 0,40 ton $(13 \%)$ \\
\hline $\mathbf{7}$ & Suruh & 2,25 ton $(100 \%)$ & 0,60 ton $(27 \%)$ & 0,78 ton $(35 \%)$ & 0,87 ton $(38 \%)$ \\
\hline $\mathbf{8}$ & Ponokawan & 3,90 ton $(100 \%)$ & 1,20 ton $(31 \%)$ & 2,70 ton $(69 \%)$ & 0,00 ton $(0 \%)$ \\
\hline $\mathbf{9}$ & Taman 1$)$ & 25,0 ton $(100 \%)$ & 0,00 ton $(0 \%)$ & 18,7 ton $(75 \%)$ & 6,30 ton $(25 \%)$ \\
\hline
\end{tabular}

1) Insinerator rusak saat disurvei

\subsection{Evaluasi kinerja insinerator}

Pada saat dilakukan survei lapangan, kondisi insinerator ada yang masih beroperasi, tidak beroperasi sama sekali atau hanya sekali-kali dioperasikan. Dilihat dari bentuk tungkunya, ada yang berbentuk segi empat (kubikal) dan tabung dengan material ada yang pelat logam maupun pasangan bata dengan masing-masing dilapis bata tahan api di dalamnya. Sedangkan kapasitas tungku mulai dari 300 kg, 600 kg, 900 $\mathrm{kg}$, dan $1.200 \mathrm{~kg}$ per 8 jam operasi (densitas 250 $\mathrm{kg} / \mathrm{m}^{3}$ ) sebagaimana diperlihatkan pada Tabel 3 . Insinerator-insinerator ini umumnya dibangun dengan pendanaan dari APBDES, APBD atau APBN serta swadaya masyarakat/CSR. Dalam survei banyak ditemui unit pembakaran ini semula dirancang berupa insinerator moduler dengan penambahan instalasi pengendalian pencemaran udara (IPPU) telah berubah fungsi menjadi tungku bakar biasa karena berbagai sebab.

Tabel 3. Jenis dan kondisi unit insinerator di TPST yang diamati

\begin{tabular}{lllll}
\hline No & $\begin{array}{c}\text { Lokasi } \\
\text { Insinerator }\end{array}$ & $\begin{array}{c}\text { Kapasitas } \\
\text { disain tungku') }\end{array}$ & \multicolumn{1}{c}{ Bentuk dan material tungku } & IPPU \\
\hline $\mathbf{1}$ & Lingkar Timur & $750 \mathrm{~kg}$ & Kotak, pasangan bata dilapis fire brick & Scrubber, tanki buffer, fan, stack \\
\hline $\mathbf{2}$ & Randegan & $900 \mathrm{~kg}$ & Kotak, plat besi pejal dilapis fire brick & Scrubber, fan, stack \\
\hline $\mathbf{3}$ & Sukorejo & $900 \mathrm{~kg}$ & Kotak, pasangan bata dilapis fire brick & Scrubber, stack \\
\hline $\mathbf{4}$ & Kragan & $600 \mathrm{~kg}$ & Kotak, plat mild steel dilapis fire brick & Scrubber, fan, stack \\
\hline $\mathbf{5}$ & Kedondong & $900 \mathrm{~kg}$ & Kotak, pasangan bata dilapis fire brick & Tangki buffer, stack \\
\hline $\mathbf{6}$ & Damarsi & $1.200 \mathrm{~kg}$ & Kotak, pasangan bata dilapis fire brick & Tidak ada \\
\hline $\mathbf{7}$ & Suruh & $600 \mathrm{~kg}$ & Kotak, plat besi pejal dilapis fire brick & Siklon, scrubber, stack \\
\hline $\mathbf{8}$ & Ponokawan & $600 \mathrm{~kg}$ & Silinder, plat besi pejal dilapis fire brick & Siklon, stack \\
\hline $\mathbf{9}$ & Taman & $600 \mathrm{~kg}$ & Kotak, pasangan bata dilapis fire brick & Scrubber, stack \\
\hline \multicolumn{7}{c}{ 1) } & Densitas sampah $250 \mathrm{~kg} / \mathrm{m}^{3} \mathrm{per} 8$ jam operasi & \\
& 2) & Diukur saat kunjungan lokasi & &
\end{tabular}


Penyebab perubahan sistem operasi dari insinerator dengan IPPU menjadi tungku bakar biasa ini disebabkan oleh kesalahan desain teknis awal pada IPPU, tidak terjangkaunya pembiayaan operasi lengkap, tidak tersedianya utilitas seperti air dan listrik sampai kepada rusaknya sistem pembakaran lengkap beberapa waktu setelah dioperasikan. Kemampuan operator dalam mengoperasikan sistem insinerator modular yang mumpuni dengan IPPU-nya juga menjadi masalah serius dalam pengoperasian insinerator-insinerator ini. Kinerja insinerator secara umum ditunjukkan melalui parameter $3 \mathrm{~T}$ (Temperature, Time, Turbulence)(14). Temperatur insinerator di tungku utama minimal $800{ }^{\circ} \mathrm{C}$, sedang waktu tinggal gas pembakaran minimal 2 sekon dan terjadi proses pengadukan sehingga memungkinkan terjadinya aliran gas yang turbulen ${ }^{(15,16)}$. Terpenuhinya $3 T$ mencegah pembentukan dioksin dan menjamin berlangsungnya pembakaran yang sempurna yang dapat diindikasikan timbulnya asap yang tidak berwarna hitam ${ }^{(17)}$.

Kinerja insinerator skala kecil secara tidak langsung juga merupakan gambaran dari kinerja sistem pengelolaan TPST secara keseluruhan. Penanggungjawab pengelolaan insinerator di Kabupaten Sidoarjo umumnya menjadi bagian dari pengelolaan TPST yang berbasis masyarakat berupa Kelompok Swadaya Masyarakat. Berdasar survei dan hasil wawancara umumnya pemasukan utama TPST berasal dari iuran warga dimana satu TPST umumnya melayani $850 \mathrm{KK}$ dengan iuran Rp. 15.000 per bulan tiap KK. Besaran pemasukan ini umumnya hanya cukup untuk pembayaran honor pekerja dan biaya transportasi sehingga tidak ada biaya untuk pemeliharaan peralatan termasuk insinerator. Gambar 1 memperlihatkan kondisi insinerator saat beroperasi. Adapun hasil evaluasi pengoperasian insinerator diperlihatkan pada Tabel 4.

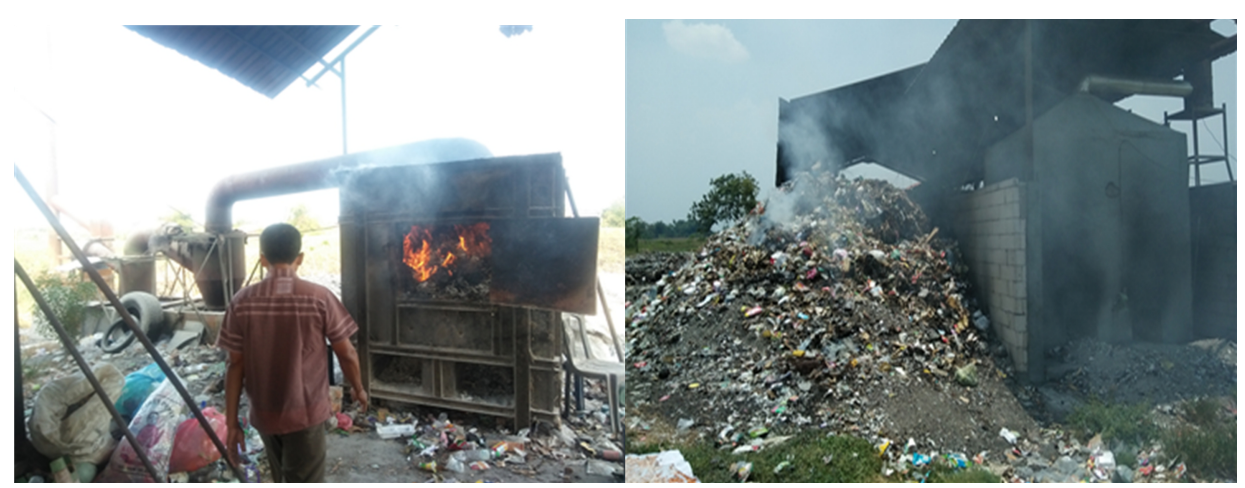

Gambar 1. Insinerator di TPST Kragan (kiri) dan di TPST Kedondong (kanan)

Tabel 4. Hasil pengamatan operasi dan dampak insinerator (bersambung)

\begin{tabular}{|c|c|c|c|c|}
\hline No & $\begin{array}{l}\text { Lokasi } \\
\text { Insinerator }\end{array}$ & Pengamatan operasi & $\begin{array}{c}\text { Dampak pada operasi dan } \\
\text { material tungku }\end{array}$ & Dampak pada lingkungan \\
\hline 1 & $\begin{array}{l}\text { Lingkar } \\
\text { Timur }\end{array}$ & $\begin{array}{l}\text { - Dinding tungku dari bata } \\
\text { merah, tidak mampu } \\
\text { menahan panas } \\
\text { - Dari perhitungan cepat } \\
\text { diperkirakan waktu tinggal } \\
\text { gas buang kurang dari } 2 \\
\text { detik } \\
\text { - IPPU tidak difungsikan } \\
\text { - Cara pengumpanan } \\
\text { sampah manual dan } \\
\text { banyak terdapat PVC dan } \\
\text { kantong kresek }\end{array}$ & $\begin{array}{l}\text { - Dinding tungku mudah } \\
\text { rontok } \\
\text { - Pembakaran tidak sempurna } \\
\text { - Tidak adanya listrik sehingga } \\
\text { mengandalkan natural force } \\
\text { draft. } \\
\text { - Berpotensi terbentuk syngas, } \\
\text { dioksin (perlu uji) } \\
\text { - Asap keluar dari pintu } \\
\text { tungku, karena IDF tidak } \\
\text { berfungsi. }\end{array}$ & $\begin{array}{l}\text { - Gas yang keluar dari tungku } \\
\text { menyebar kesekitar area } \\
\text { dengan radius pendek } \\
\text { - Kontruksi besi banyak } \\
\text { keropos menunjukkan kadar } \\
\text { asam di dalam gas buang } \\
\text { tinggi } \\
\text { - Pekerja terpapar asap yang } \\
\text { keluar dari pintu tungku. }\end{array}$ \\
\hline 2 & Randegan & $\begin{array}{l}\text { - Suhu pembakaran } \pm 187^{\circ} \mathrm{C} \\
\text { - Tidak ada jaringan listrik } \\
\text { - Dari perhitungan cepat } \\
\text { waktu tinggal gas }<2 \text { detik } \\
\text { - Tekanan dalam tungku } \\
\text { positif } \\
\text { - IPPU tidak difungsikan }\end{array}$ & $\begin{array}{l}\text { - Pembakaran tidak sempurna } \\
\text { - Tidak adanya listrik sehingga } \\
\text { mengandalkan natural force } \\
\text { draft. } \\
\text { - Terbentuk syngas } \\
\text { - Asap keluar dari pintu tungku } \\
\text { - Pekerja terpapar asap yang } \\
\text { keluar melalui pintu } \\
\text { pemasukan umpan }\end{array}$ & $\begin{array}{l}\text { - Berpotensi terbentuk } \\
\text { dioksin (perlu diuji) } \\
\text { - Gas yang keluar dari tungku } \\
\text { menyebar kesekitar area } \\
\text { dengan radius pendek } \\
\text { - Kontruksi besi banyak yang } \\
\text { rusak dan keropos } \\
\text { menunjukkan kadar asam di } \\
\text { dalam gas buang tinggi }\end{array}$ \\
\hline
\end{tabular}


Tabel 4. Hasil pengamatan operasi dan dampak insinerator (sambungan)

\begin{tabular}{|c|c|c|c|c|}
\hline No & $\begin{array}{l}\text { Lokasi } \\
\text { Insinerator }\end{array}$ & Pengamatan operasi & $\begin{array}{c}\text { Dampak pada operasi dan } \\
\text { material tungku }\end{array}$ & Dampak pada lingkungan \\
\hline 3 & Sukorejo & $\begin{array}{l}\text { - Suhu pembakaran } 90^{\circ} \mathrm{C} \\
\text { - Waktu tinggal gas } \\
\text { pembakaran }<2 \text { detik } \\
\text { - Tekanan dalam tungku } \\
\text { positif } \\
\text { - IPPU sederhana dan tidak } \\
\text { difungsikan }\end{array}$ & $\begin{array}{l}\text { - Pembakaran tidak sempurna } \\
\text { - Berpotensi terbentuk syngas } \\
\text { - Asap keluar dari pintu tungku } \\
\text { - Pekerja terpapar asap yang } \\
\text { keluar melalui pintu } \\
\text { pemasukan umpan }\end{array}$ & $\begin{array}{l}\text { - Potensi terbentuk dioksin } \\
\text { - Gas yang keluar menyebar } \\
\text { ke sekitar area dengan } \\
\text { radius pendek } \\
\text { - Kontruksi besi banyak yang } \\
\text { rusak dan keropos, kadar } \\
\text { asam di dalam gas buang } \\
\text { tinggi }\end{array}$ \\
\hline 4 & Kragan & $\begin{array}{l}\text { - Suhu pembakaran } \pm 342{ }^{\circ} \mathrm{C} \\
\text { - Dari perhitungan cepat } \\
\text { waktu tinggal gas } \\
\text { pembakaran }<2 \text { detik } \\
\text { - Tekanan dalam tungku } \\
\text { positif } \\
\text { - IPPU tidak difungsikan, } \\
\text { - IDF tidak dipasang motor } \\
\text { penggerak }\end{array}$ & $\begin{array}{l}\text { - Pembakaran belum } \\
\text { sempurna } \\
\text { - Berpotensi terbentuk syngas } \\
\text { - Asap keluar dari pintu tungku } \\
\text { - Pekerja terpapar asap yang } \\
\text { keluar melalui pintu } \\
\text { pemasukan umpan }\end{array}$ & $\begin{array}{l}\text { - Potensi terbentuk dioksin } \\
\text { - Gas yang keluar dari tungku } \\
\text { menyebar kesekitar area } \\
\text { dengan radius pendek } \\
\text { - Area dekat pemukiman } \\
\text { mudah terjadi konflik. }\end{array}$ \\
\hline 5 & Kedondong & $\begin{array}{l}\text { - Suhu pembakaran } \pm 110^{\circ} \mathrm{C} \\
\text { - Waktu tinggal gas }<2 \text { detik } \\
\text { - Tekanan dalam tungku } \\
\text { positif } \\
\text { - IPPU tidak berfungsi, tidak } \\
\text { ada IDFan } \\
\text { - Ada pengarah gas buang } \\
\text { menuju ke cerobong }\end{array}$ & $\begin{array}{l}\text { - Pembakaran tidak sempurna } \\
\text { - Terbentuk syngas }\end{array}$ & $\begin{array}{l}\text { - Potensi terbentuk formasi } \\
\text { dioksin } \\
\text { - Asap yang mengandung } \\
\text { senyawa beracun } \\
\text { terdispersi ke sekitar tungku }\end{array}$ \\
\hline 6 & Damarsi & $\begin{array}{l}\text { - Suhu pembakaran } \pm 90{ }^{\circ} \mathrm{C} \\
\text { - Waktu tinggal gas }<2 \text { detik } \\
\text { - Tekanan dalam tungku } \\
\text { positif } \\
\text { - IPPU tidak ada }\end{array}$ & $\begin{array}{l}\text { - Pembakaran tidak sempurna } \\
\text { - Terbentuk syngas } \\
\text { - Asap keluar dari cerobong } \\
\text { dan lubang samping tungku } \\
\text { - Lubang samping bisa } \\
\text { mengalirkan udara sekunder } \\
\text { pada saat ada angin ke } \\
\text { tungku. }\end{array}$ & $\begin{array}{l}\text { - Potensi terbentuk dioksin } \\
\text { (perlu diuji) } \\
\text { - Asap yang mengandung } \\
\text { senyawa beracun } \\
\text { terdispersi ke sekitar tungku }\end{array}$ \\
\hline 7 & Suruh & $\begin{array}{l}\text { - Suhu pembakaran } 350^{\circ} \mathrm{C} \\
\text { - Waktu tinggal gas }<2 \text { detik } \\
\text { - Tekanan dalam tungku } \\
\text { positif } \\
\text { - IPPU tidak berfungsi } \\
\text { karena desain kurang tepat }\end{array}$ & $\begin{array}{l}\text { - Pembakaran belum } \\
\text { sempurna } \\
\text { - Terbentuk syngas } \\
\text { - Asap menyebar di area } \\
\text { TPST }\end{array}$ & $\begin{array}{l}\text { - Potensi terbentuk dioksin } \\
\text { - Gas yang keluar dari tungku } \\
\text { menyebar deakt kesekitar } \\
\text { area Kontruksi besi banyak } \\
\text { yang rusak dan keropos. }\end{array}$ \\
\hline 8 & Ponokawan & $\begin{array}{l}\text { - Suhu pembakaran } 400{ }^{\circ} \mathrm{C} \\
\text { - Waktu tinggal gas }<2 \text { detik } \\
\text { - Tekanan dalam tungku } \\
\text { positif } \\
\text { - IPPU tidak berfungsi } \\
\text { karena rusak }\end{array}$ & $\begin{array}{l}\text { - Pembakaran belum } \\
\text { sempurna } \\
\text { - Terbentuk syngas } \\
\text { - Asap menyebar di area } \\
\text { TPST }\end{array}$ & $\begin{array}{l}\text { - Potensi terbentuk dioksin } \\
\text { - Gas yang keluar dari tungku } \\
\text { menyebar ke sekitar area } \\
\text { dengan radius pendek } \\
\text { - Kontruksi besi banyak yang } \\
\text { rusak dan keropos }\end{array}$ \\
\hline 9 & Taman & $\begin{array}{l}\text { - Tungku bakar dari dinding } \\
\text { bata ringan } \\
\text { - Pintu pemasukan sampah } \\
\text { berada di area bagian } \\
\text { bawah grate } \\
\text { - Saat diruvei sedang tidak } \\
\text { beroperasi } \\
\text { - IPPU terdiri atas cyclone, } \\
\text { scrubber, dan dilengkapi } \\
\text { dengan IDF } \\
\text { - Abu pembakaran tidak } \\
\text { dikelola }\end{array}$ & $\begin{array}{l}\text { - Mudah retak karena tidak } \\
\text { mampu untuk suhu tinggi } \\
\text { - Pekerja susah untuk } \\
\text { memasukkan sampah } \\
\text { secara merata. } \\
\text { - Kondisi operasi tungku tidak } \\
\text { diketahui } \\
\text { - Desain cyclone kurang tepat } \\
\text { dan pemipaan IPPU dimana } \\
\text { pipa keluar cyclone } \\
\text { dimasukkan ke dalam bak air } \\
\text { akan menghambat daya } \\
\text { hisap IDF menuju cerobong }\end{array}$ & $\begin{array}{l}\text { - Pengamatan di lapangan } \\
\text { atap hangar dan kontruksi } \\
\text { besi banyak yang rusak dan } \\
\text { keropos menunjukkan kadar } \\
\text { asam di dalam gas buang } \\
\text { tinggi } \\
\text { - Area yang dekat dengan } \\
\text { pemukiman mudah terjadi } \\
\text { konflik. }\end{array}$ \\
\hline
\end{tabular}




\section{KESIMPULAN}

Berdasarkan hasil survei lapangan dan kajian mendalam dalam penelitian ini maka dapat ditarik beberapa kesimpulan.

1. Sistem pemusnahan sampah dengan pembakaran melalui tungku bakar biasa dan insinerator modular pada TPST yang diteliti mampu mereduksi $20-30 \%$ dari sampah yang masuk ke TPST tersebut. Sedangkan dari total sampah yang dikelola melalui TPST dan TPS 3R Kabupaten Sidoarjo, pembakaran sampah mampu mereduksi $3,5 \%$ dari total sampah yang dibawa ke TPST dan TPS 3R.

2. Dari seluruh insinerator yang ada di TPST yang diteliti menunjukkan sistem operasi yang tidak sesuai standar yang seharusnya (under performance) dilihat dari kondisi suhu pembakaran yang kurang dari $850{ }^{\circ} \mathrm{C}$, waktu tinggal gas buang secara perhitungan kurang dari 2 detik, turbulensi tidak terjadi dari pengamatan secara visual dan tidak adanya proses percampuran sampah di tungku, komposisi sampah yang dibakar masih banyak berpotensi mengandung B3, pengendalian gas buang (fasilitas IPPU) yang tidak berfungsi, serta tidak adanya pengelolaan abu/residu pembakaran hingga rendahnya aspek keselamatan operator.

3. Pembiayaan operasional TPST masih sangat rendah terkait kemampuan masyarakat dalam membayar iuran bulanan. Hal ini juga menjadi salah satu penyebab tidak adanya biaya operasional dan pemeliharaan insinerator.

4. Walaupun hingga saat ini belum terlihat adanya protes masyarakat terkait asap sisa pembakaran sampah namun untuk mengantisipasinya perlu upaya peningkatan kinerja insinerator eksisting saat ini dengan memperbaiki kondisi operasi di tungku dan peningkatan kemampuan IPPU serta harus dilakukan pemantauan kualitas emisi gas buang secara periodik.

\section{PERSANTUNAN}

Ucapan terima kasih sampaikan kepada pihak Dinas Lingkungan Hidup dan Kebersihan Kabupaten Sidoarjo yang sudah memfasilitasi terlaksananya penelitian dalam rangka evaluasi keberadaan insinerator skala kecil di TPST di Kabupaten Sidoarjo.

\section{DAFTAR PUSTAKA}

1. Dinas Lingkungan Hidup dan Kebersihan. (2017). Renstra OPD Final Dinas Lingkungan Hidup dan Kebersihan (2016-2021) Kabupaten Sidoarjo.
2. Badan Pusat Statistik (BPS) Kabupaten Sidoarjo. (2018). Kabupaten Sidoarjo Dalam Angka 2018.

3. Laili, V. R. (2017). Strategi peningkatan operasional TPST di Kabupaten Sidoarjo (Doctoral dissertation, Institut Teknologi Sepuluh Nopember).

4. Peraturan Menteri Pekerjaan Umum Nomor 3 Tahun 2013 tentang Penyelenggaraan Prasarana dan Sarana Persampahan Dalam Penanganan Sampah Rumah Tangga dan Sampah Sejenis Sampah Rumah Tangga.

5. Peraturan Menteri Lingkungan Hidup dan Kehutanan Nomor 70 Tahun 2016 tentang Baku Mutu Emisi Usaha dan/atau Kegiatan Pengolahan Sampah Secara Termal.

6. Ashworth, D. C., Fuller, G. W., Toledano, M. B. Font, A., Elliott, P., Hansell, A. L., \& de Hoogh, K. (2013). Comparative assessment of particulate air pollution exposure from municipal solid waste incinerator emissions. Journal of environmental and public health, 2013.

7. Gaol, M. L., \& Warmadewanthi, I. D. A. A. (2017). Prediksi dampak lingkungan pengelolaan sampah di TPA Jabon, Kabupaten Sidoarjo. Jurnal Teknik ITS, 6(2), F451-F455.

8. BPPT. (2010). Neraca Emisi Gas Rumah Kaca Sektor Limbah - Laporan Akhir. Pusat Teknologi Lingkungan-Badan Pengkajian dan Penerapan Teknologi.

9. Di Maria, F., \& Sisani, F. (2018). Effectiveness of municipal solid waste incinerators in replacing other fuels. A primary energy balance approach for the EU28. Waste Management \& Research, 36(10), 942-951.

10.Zhang, G., Huang, X., Liao, W., Kang, S., Ren, M., \& Hai, J. (2019). Measurement of dioxin emissions from a small-scale waste incinerator in the absence of air pollution controls. International journal of environmental research and public health, 16(7), 1267.

11. Choy, K. K., Porter, J. F., Hui, C. W., \& McKay, G. (2004). Process design and feasibility study for small scale MSW gasification. Chemical Engineering Journal, 105(1-2), 31-41.

12. Damanhuri, E. (2006). Aspek teknologi dalam peningkatan pengelolaan sampah. Paper workshop. Departemen Pekerjaan Umum. Jakarta.

13. Batterman, S. (2004). Findings on an Assessment of Small-scale Insinerators for Health-care waste. World Health Organization (WHO). 
14.Purwanta, W., \& Suryanto, F. (2018). Perancangan ID Fan dan Cerobong pada Unit Pembangkit Listrik Tenaga Sampah. Jurnal Teknologi Lingkungan, 19(2), 173-182.

15. Niessen, W.R. (2002). Combustion and Incineration Process. Marcel Dekker, Inc. New York.
16. WORLD BANK. (1999). Technical Guidance Report, Municipal Solid Waste Incineration, Washington, D.C. 20433, U.S.A.

17. Kikkawa, H., Ishizaka, H., Kai, K., Nakamoto, T. (2008). DeNOx, DeSOx, and CO2 removal technology for power plant. Hitachi Review. Vol 57 , No.5. 